\title{
How to integrate invisible geomorphosites in an inventory: A case study in the Rhone River valley (Switzerland)
}

\author{
Mélanie Clivaz ${ }^{1}$, Emmanuel Reynard ${ }^{1}$ \\ ${ }^{1}$ University of Lausanne, Institute of Geography and Sustainability, Géopolis, CH-1015 Lausanne, Switzerland.
}

\begin{abstract}
During the two last decades, numerous inventories of geosites have been carried out at various scales. They aim at documenting the state of the geological heritage, which is the basis for management strategies. In very humanized regions, where the original geomorphology has been highly modified by human infrastructures, agriculture, urban sprawling, and various modifications of landforms, it is important to inventory not only the landforms visible today but also former landforms destroyed or hidden by human activities. To address the issue of inventorying invisible geomorphosites, two approaches were tested in the Rhone River valley (Switzerland). The first was an inventory of geomorphosites of the study area. Not only the visible landforms but also the landforms that had completely disappeared were evaluated with the assessment method of the University of Lausanne. A total of 28 geomorphosites were assessed including five missing sites (two sand dunes areas, a braided sector of the Rhone River and two former marshes). These invisible geomorphosites were assessed and their management was discussed. The second study was a multi-method analysis of former landscapes of the $19^{\text {th }}$ century. Several data including historical maps, written archives, digital terrain model and iconographic sources were combined and allowed the reconstruction of palaeolandscapes and landforms. Both materials allowed proposing a strategy for geotourism development.
\end{abstract}

Keywords: Geoheritage, Geomorphosites, Invisibility, Inventory, Palaeolandscape

\section{Introduction}

Since the early 1990's, there has been a growing interest for geoheritage and its protection in many parts of the world (O'Halloran et al. 1994; Sharples 2002; Gray 2004; Brilha 2005; Reynard et al. 2009a) and research on geosites has spread rapidly (Reynard and Coratza 2013; Brilha 2016). Geosites are not only an essential component of the landscape, but they are also witnesses of the Earth history (Grandgirard 1997). Many of them have formed under specific conditions, climatic or geological, that are now inactive, which makes damages to these sites irreversible (Strasser et al. 1995). The need for nature conservation is widely accepted by natural scientists and authorities. However, the protection of geoheritage and geodiversity continues to lag behind the protection of biodiversity (Gray 2004). Governments and nature conservation associations tend to emphasise the need for the conservation of biotic elements and to ignore the geological foundation on which the biodiversity is built and has evolved (Pemberton 2001), even if recently the importance of geoconservation has been recognised by nature conservation organisations at the international level (Crofts and Gordon 2015).

During the last two decades, several guidelines have been proposed to inventory and evaluate the quality of the geoheritage (see Brilha 2016 for a review) and numerous inventories of geosites have been carried out at various scales. They aim at documenting the state of geoheritage, which is the basis for the adoption of management strategies (geoconservation, geoeducation, geotourism, etc.). This paper focuses on geomorphosites, i.e. sites of geomorphological interest (Panizza 2001). By geomorphological interest, we consider both a central (scientific) value, for their interest for reconstructing the Earth history, and several additional values (aesthetic, cultural, ecological and economic), important to address the links between the landforms and society (Reynard 2005). Geomorphosites have some particularities if compared to other types of geosites (e.g. palaeontological sites, mineralogical sites, etc.) (Reynard 2009a): their aesthetic component is often very important, which can hide their interest for the knowledge of Earth history; the processes at the origin of their formation are often still active, which could make geomorphosites change in the future; finally, geomorphosites often combine several spatial scales (micro- and meso-landforms are often imbricated in large landscapes) and several temporal scales (active processes are often mixed with fossil elements), which makes their delineation and characterisation sometimes difficult.

Moreover, a large number of geomorphosites are not clearly identified due to their invisibility (Tooth 2009; Giusti 2012; Cayla et al. 2012). The question of geomorphosite invisibility may be considered at two levels. First, it is related to the fact that the 
discipline of geomorphology is little known by specialists of other disciplines and by the society in general, as was addressed by Tooth (2009) or Giusti (2012). Second, the landforms are not visible for the eyes of non-specialists, which are often the persons that should develop management strategies in order to protect (conservationists, which are often nongeomorphologists) or promote (tourism specialists, teachers) the geomorphological heritage, and also the people that use the geomorphosites (scholars, tourists). This invisibility is due to a kind of mask that obstacles a correct perception of the characteristics and the quality of geomorphosites (Cayla et al. 2012). These authors consider four types of invisibility. First, it can be original (or genetic) as for underground cavities or undersea landforms. Second, it may be due to the limits of perception itself when a part of the site or the whole site is hidden, when a site is visible only from certain angles, or in the case of megasites (e.g. impacts of meteorites) not perceptible by human eye. Third, it can be due to the "mask of picturesque", i.e. the reduction of the site's quality to its aesthetic or spectacular characteristics, which hides other interests (e.g. scientific ones). Fourth, landforms can be hidden or destroyed by natural processes (e.g. volcanic eruptions) or human activities (e.g. drained wetlands, river training, etc.). The invisibility discussed in this paper concerns this last case.

In very humanized regions, the original geomorphology has often been highly modified by human infrastructures, agriculture, urban sprawling and various modifications of the landforms. The question of the place of invisible forms in geoheritage has been little studied to date and remains open. In particular two main questions need to be addressed: (1) Which methods allow the reconstruction of palaeolandscapes and landforms? (2) Which interpretation and promotion strategies can be developed to make the invisible geomorphosites understandable by the public? The geohistorical approach - considered here in its geographical acceptance - i.e. a methodology that combines geographical and historical analysis of phenomena (Braudel 1949; Baker 2003; Jacob-Rousseau 2009; Grataloup 2015) - and not in its Earth science acceptance - i.e. the discipline that studies the history of the Earth (e.g. Ozima, 1987) - seems to be ideal. In particular former landscapes and landforms that have been destroyed by human activities can be reconstructed by processing historical maps in GIS environment (Baud and Reynard 2015). Inventories of geomorphosites in these humanized areas should therefore consider not only the landforms visible today but also former landforms that have been destroyed or hidden by human activities. To address the issue of inventorying invisible geomorphosites, these two approaches - geohistorical analysis of landscape changes and geomorphosite inventory have been tested in a sector of the Rhone River valley, in Switzerland (Fig. 1). Historical landscapes were reconstructed and geomorphosites, including invisible forms, were assessed and their management was discussed. Proposals for their interpretation within education programs and their usefulness for improving the awareness of former landscapes by the public were discussed.

\section{Methodology}

Two combined methods were used: inventory of geomorphosites and geohistorical analysis. The inventory of geomorphosites was carried out in the sector of the valley comprised between Agarn and Martigny (Fig. 1). The objective was to select sites giving a good overview of the regional morphogenesis. Various inventory methodologies (e.g. Coratza and Giusti 2005; Serrano and Gonzáles Trueba 2005; Bruschi and Cendrero 2005; Pereira and Pereira 2010) have the common goal of assessing and selecting geoheritage features that are traduced by different values: scientific, ecological, cultural, aesthetic, economic, educational, etc. (Reynard 2005, 2009). The University of Lausanne developed a method for assessing the scientific and additional values of geomorphosites at the regional scale (Reynard et al. 2007, 2016) (Fig. 2). The inventory is divided in two steps: the selection and the assessment of geomorphosites (see Reynard et al. 2016 for details).

The geomorphosites included in an inventory should be characteristic of the regional geomorphological features. This is why the selection of landforms that will be assessed is an important stage in the inventory process (Perret 2014). It is divided in four steps. First, the geomorphological contexts are defined and the main geomorphological processes are listed. A first list of landforms is then established. It is based on consultation of literature, cartographic and photogrammetric material (topographic maps, geologic maps, digital terrain models (DTM), aerial photographs), on field survey and on assessor's knowledge. The listed landforms are then classified following a spatial criterion (representative landforms versus rare landforms) and a temporal criterion (active landforms versus inherited landforms) (Fig. 3). The last stage is the establishment of a list of sites representative of the geomorphological contexts and of various stages of the regional morphogenesis. This list contains both inherited and active landforms as well as common and rare landforms.

The assessment procedure is divided in four main stages (Fig. 2; see Reynard et al. 2016 for details):

- Description of the site: for each inventoried site, general data (coordinates, altitudes, etc.) are collected, and a description, a simplified geomorphological map and an explanation of the morphogenesis are realised;

- Assessment of the intrinsic value: the central or scientific value and the additional values - including ecological, aesthetic and cultural values - are evaluated;

- Use and management characteristics: the present use and management features are documented taking into account both the protection of the site (protection status, damages and threats) and its promotion (visit conditions - accessibility, security, site context, tourism infrastructures - and educational facilities and interests); 
- Synthesis: it gives an overview of the intrinsic value, the use and management characteristics, and some protection or promotion measures are proposed.

The geohistorical analysis covered a shorter area. It was applied in the sector of the valley comprised between Sion and Martigny (Fig. 1). The geohistorical approach aims to identify trajectories, permanence and changes in territories through a diachronic perspective (Grataloup 2005). In this regard, the iconographic and textual archives make up the main material of a geohistorical study. In this study, the objective was to reconstruct palaeolandscapes with a focus on palaeolandforms. Several data like historical maps, place names, written archives, DTM and iconographic sources (Reynard et al. 2011) were combined in a Geographic Information System (GIS) environment (Fig. 2) and allowed the reconstruction of palaeolandforms. Several maps produced by the Swiss government were used: the original surveys and Dufour maps (1839 and 1865), the Siegfried atlas (between 1879 and 1926), the national maps of Switzerland (since 1938) (for cartographic details, see Stäuble et al. 2008; Reynard 2009b and Baud et al. 2015). Regressive mapping (from the younger to the older documents) - a commonly used approach since the generalization of GIS (Baud 2009; Franchomme and Schmidtt 2012) - was conducted in ArcGIS environment and land use shown in the cartographic corpus was categorized and digitized. Synchronous maps showing the state of land use at a specific time, diachronic maps showing land use changes through time and transition matrices showing land use paths (i.e. transitions from one use class to another) between the selected reference states allowed us to represent and to quantify land use and landscape changes (Baud and Reynard 2015; Baud et al. 2015). To understand and explain the identified land use trajectories several archive funds were consulted in the State Archives of Valais, which allowed us to reconstruct the activities and practices associated with landscapes of the past and to identify those responsible of ruptures and changes.

\section{Study area}

The study area is a stretch of the Rhone River valley, up-stream of Lake of Geneva, in the Western Swiss Alps (Fig. 1). Here, the Rhone River flows in a glacial valley limited by two high mountain ranges: the Bernese Alps in the North and the Pennine Alps in the South. Climate is semi-continental, characterized by heavy rain-shadow effect (typical annual rainfall rate is below $600 \mathrm{~mm}$ ), high insulation and warm temperature in summer, snowfall and cold temperature in winter. The geomorphology is characterised by extensive structural landforms and numerous relict forms of Quaternary glaciations. Structural landforms and associated gravity landforms (landslides, rockslides) are mainly related to the contact of two main tectonic domains (Penninic and Helvetic) and the presence of the Rhone-Simplon line (Hubbard and Mancktelow 1992; Egli and Mancktelow 2013), a large fault zone running from the Ossola valley (Italy) to the Mont Blanc massif, which separates the two domains. The Rhone River valley follows this line from Brig to Martigny. Multiple glaciations shaped the Rhone River valley during the Quaternary (Bini et al. 2009; Valla et al. 2011; Stutenbecker et al. 2016). The glaciers eroded the bedrock, released numerous landforms (moraines, erratic blocks), especially in the tributary valleys, and glacial and post-glacial sedimentation filled the glacial depressions (see Reynard et al. 2009b for a review). Currently, the active processes are mainly fluvial in the valley floor and gravitational in the slopes.

In contrast with the two valley slopes, which are quite steep due to glacial erosion, the topography of the bottom of the valley is relatively flat. In the studied sector the slope gradient is less than 3.5\% (Montané et al. 2010) because of post-glacial infilling. Because of the high number of alluvial fans built by tributaries at their confluence with the Rhone River, the route of the river is sinuous in the valley floor that can reach several kilometres in largeness. For centuries, the river was flowing quite freely on the floodplain bottom and alternated - both in time and space - braided and meandering sectors. As for numerous other rivers in the Alps (Bravard 1989), a fluvial metamorphosis of the Rhone River certainly happened during the Little Ice Age, with the braided character of the river becoming more extended for both (more humid) climatic and anthropic (deforestation) reasons. Tributaries fed by glaciers and snow-melting as well as torrential systems were building alluvial fans at their confluence with the Rhone River, and more or less extensive wetlands (Gams 1914; Farquet 1925) were isolated by these alluvial fans and the braided sectors of the main river. Floods were frequent and temporary lakes were forming during the snowmelt season (May-August) and during intense rainfall events, in particular in autumn. Even sand dunes were visible in several places due to remobilisation of fine fluvial deposits by wind processes (Gams 1914; Farquet 1925).

The landscape changed a lot since the mid- $19^{\text {th }}$ century when important works were undertaken to channelize the river and its tributaries. A high flood caused catastrophic damages in the plain in 1860 and led to the systematic channelization of the river between 1863 and 1894, followed by a second river training project undertaken between the 1930s and the 1960s (De Torrenté 1964; Mariétan 1968). Since, 91.6\% of the Rhone River channel length (Weber et al. 2007) and the majority of its tributaries were completely channelized; $95 \%$ of the alluvial zones and $85 \%$ of the wetlands were replaced by other land uses (Zanini et al. 2009), in particular farming land. The sand dunes were completely destroyed, partly for filling depressions, and most wetlands were drained during the first half of the 20 ${ }^{\text {th }}$ century (Gams 1914; Farquet 1925; Reynard and Baud 2015). Consequently, the plain dependent on river processes was gradually transformed into a very humanized plain where agricultural, industrial and tertiary activities dominate the landscape (Stäuble and Reynard 2005). 
It is estimated that today about hundred thousand people are living in the research area, with the majority of them in mediumsize towns (Sion, 30,000 inhabitants in 2015; Martigny, 18,000 inhabitants in 2015; Sierre, 16,500 inhabitants in 2015). The population of the Canton of Valais - i.e. the political territory in which the Rhone River valley is situated - has increased by $21 \%$ in the last twenty years. The annual growth rate (1.6\% in 2013) is higher than the national average (1.1\% in 2013$)$ and the population is expected to continue to grow in the coming years. The communication infrastructures network (roads, railways) is well developed. Martigny is located on the crossroads between France (Chamonix) and Italy (Aosta valley). Localities are also well served by public transport infrastructures. Speaking of economy, 6\% of the active population is employed in the primary sector, $20 \%$ in the secondary sector and $74 \%$ in the tertiary sector, in particular tourism. Since the 1960s, Valais is known as a winter tourism destination but important efforts are now made to develop summer tourism (hiking, cycling) and inter-season tourism, as well as new forms of tourism (wine tourism, cultural tourism) to compensate the decrease of the ski sector. Geotourism has a great potential (Reynard 2016) but is very poorly developed.

\section{The geomorphosite inventory}

The geomorphosite inventory (Clivaz 2015) includes 28 sites (Fig 4) related to seven geomorphological processes: fluvial (alluvial fans, gorges, channels), gravity (landslides, rockslides), glacial (erratic boulders, glacial hills), karstic (springs, underground lake), wind (dunes), anthropogenic (accumulation of stones, dikes) and moors and lakes. The distribution of the geomorphosites according to the morphogenetic processes is related to their importance in the morphogenesis of the Rhone River valley. Fluvial landforms are the most numerous (11 sites), followed by lakes and moors ( 5 sites).

Among the inventoried geomorphosites, five are missing geomorphosites: two sand dunes (sites 23, 25), a former braided sector (site 8) and two former moors (sites 17, 22). Sand dunes were present in the alluvial plain before the river training works. They were mainly situated along the Rhone River a few kilometres upstream of Martigny (Fig. 5A, 6). Their presence is explained by three factors (Reynard et al. 2011): the availability of fine sand sediments deposited by the river; the presence of the Dranse alluvial fan that reduced the slope gradient of the Rhone River upstream of Martigny, which consequently increased the deposition of fine sediments; the presence of strong winds due to the particular location of Martigny at the crossroad of four valleys (the Upper Rhone valley, the Dranse valley, the Forclaz pass and the Rhone gorge downstream of Martigny) capable to reorganise sand deposits in form of dunes. These dunes impressed the travellers and the scientists (e.g. Morlot 1857; Gams 1914; Farquet 1925). They have been completely removed for filling depressions and wetlands (Fig. 6A). The Sarvaz dunes (site 23) - not more than 3m high - covered an area about one kilometre long near a former braided sector of the Rhone River in Saillon (Fig. 5A). The Crêtes and Indes dunes, in Charrat, were higher (15-20m) and organized in two lines parallel to the Rhone River. Because of their size they attracted scientists (Morlot 1857; Farquet 1925). They also have completely disappeared because of sand extraction and railway line construction. Braided sectors were very common before the river training works. Except the Finges area (site 3), all these braided areas have disappeared due to river channelization. One particularly well-developed braided sector was included in the inventory (site 8 , in Chalais). This $1.3 \mathrm{~km}$ large braided sector was occupying nearly half of the valley in the mid-19 ${ }^{\text {th }}$ century (Laigre 2009; Fig. 6C) and it has been replaced by farming land after the river training (Stäuble 2009). Moors were also very common in the $19^{\text {th }}$ century and most of them were drained. Two of them were included in the inventory. The Praz-Pourris moor (site 17) was a large wetland area (250 ha) considered to have a very high biodiversity (Rey 2008) and now completely drained and occupied by farming land and urbanised areas (Stäuble and Reynard 2005). A geohistorical analysis (Pasche 2004; Stäuble and Reynard 2005; Fig. 6D) allowed us to reconstruct the stages of the drainage works: even if the Rhone River was already embanked in the 1860s it was not before World War II that the moor was systematically drained to gain crops. Now only some place names $($ Praz-Pourris $=$ wet meadows; Les Fougères $=$ ferns) remember the presence of former wetlands. The Sarvaz moor (site 22) was close to the Sarvaz dunes. It presented a very high biodiversity and was fed with water by the karstic Sarvaz spring whose nival regime was responsible of the formation of temporary lakes (up to $2 \mathrm{~km}^{2}$ ) in the early summer (Gams 1914). Since 1914 systematic drainage transformed the area in intensive crops (Thurre 2013).

The map of Fig. 7 shows the intrinsic value of the geomorphosites. The size of circles represents the scientific value and the main additional values are indicated by pictograms. Many sites have a high scientific value, e.g. Venetz erratic boulder (site 14; 0.94 on a scale from 0 to 1 ), Sierre rockslide (site 6; 0.88) and Montagnon landslide (site 20; 0.88). Urbanised alluvial fans of the Morge (site 16) and Dranse (site 27) rivers have the lowest scientific value (0.38) due to their low integrity. The invisible geomorphosites have a medium value, principally because their integrity is zero: Sarvaz dunes (0.63), Crêtes and Indes dunes (0.63), braided sector of Chalais (0.44), Praz-Pourris moor (0.5), Sarvaz moor (0.63).

The evaluation of additional values including ecological value, aesthetic value and cultural value is qualitative. The ecological value is broadly low (Fig. 7). Only four landforms have an influence on ecology and biodiversity: the alluvial zone of the Rhone River in Finges (site 3), Sierre rockslide (site 6), Borgne gorges (site 12) and the palaeochannel Bras de Quiess (site 24). The aesthetic value takes into account the observation possibilities, the contrasts and the vertical development. Many sites have a very high or high aesthetic value. This is the case of Borgne gorges (site 12), Sierre rockslide (site 6), Valère and Tourbillon hills (site 13) or La Bâtiaz hill (site 28). Disappeared sites have a very low aesthetic value because there is no 
possibility of observation. Over half of landforms have a low cultural value. Some sites have a religious importance: religious buildings are located on the Sierre rockslide deposits (site 6) and on Valère hill (site 13). Some other landforms have a historical importance: archaeological remains have been discovered near the Pierre du Meurtrier fallen block (site 7) and on the Dranse alluvial fan (site 27). Because they have disappeared from the landscape, invisible geomorphosites have no cultural value except the Sarvaz moor. In that case, a legend recalls hydro-geomorphological processes. According to the legend a village was present in La Sarvaz but it was flooded by the wrath of God because people were not sufficiently pious. Moreover, the former landscapes are reminded by numerous written descriptions (Farquet, Lenthéric, Daudet) or paintings (Rehfous, Muret).

The majority of inventoried sites are affected in their integrity or threatened by human activities (Fig. 8). Human activities are the major cause of the damages, which can affect not only the integrity of the sites, but also their ecological value or their visibility. Four of the five invisible geomorphosites have been completely destroyed. Only for the Sarvaz moor the situation is a little bit better because one of the drainage channels has been revitalised recently. Biologists hope that seed of former plants could have been buried and could be reactivated by the rehabilitation works. Fig. 8 shows also the protection status of inventoried sites. The degree of protection of more than half of the sites is considered as insufficient. In Switzerland geosites are often protected in an indirect way, through the protection of biotopes or landscapes as no specific regulation concerns the geoheritage (Reynard 2012). Only two inventoried geomorphosites have a very high level of protection: the alluvial zone of the Rhone River in Finges (site 3) and deposits of Sierre rockslide (site 6). They are part of the Natural Regional Park PfynFinges and are included in the Federal Inventory of Landscapes and Natural Monuments of National Importance (ILNM). Additionally, other protective measures were taken by the Canton of Valais in favour of these two sites. Eight sites, which are affected in their integrity have a bad protection status. Among these sites are four disappeared sites and three urbanised alluvial fans.

Visit conditions and educational potential of geomorphosites are represented on Fig. 9. All sites have good visit conditions in terms of accessibility by public transports but most geomorphosites are situated in a disturbed environment. Indeed, people visiting the site can be bothered by road, railway or other noise due to their proximity to urban or industrial zones. Disturbed environment is indicated by a pictogram on map of Fig. 9. There are few geotourism activities or interpretation panels in the Rhone River valley. Most of the panels are related to the ecological characteristics and only three geomorphosites have panels presenting geo(morpho)logy: Raspille gorges and springs (site 4), Raspille earth pyramids (site 5) and Losentse alluvial fan (site 19).

\section{The geohistorical analyses}

Geohistorical analyses were concentrated in a restricted sector, between Sion and Martigny (Fig. 1). The main objective was the reconstruction of land-use trajectories by using a set of historical maps. The analysis was conducted both at the scale of the whole sector (maps of Fig. 5; Baud et al. 2015) and in specific areas as Pouta Fontana moor (Fig. 6D; Stäuble and Reynard 2005). Geohistorical analyses allowed us to understand the pace of land use change; indeed, even if the Rhone River embankment happened in the 1860s, it is not before the 1920-1930 decades that the marshes were systematically drained (Fig. 5B). The reason is mainly financial and it is after the Swiss Confederation accepted to subsidize the drainage works that the wetlands were systematically dried (Baud et al. 2015; Reynard and Baud 2015). Indeed, only 82 ha of 939 ha of wetlands were dried between 1840 and $1880(-9 \%)$ and 166 ha $(-19 \%)$ between 1880 and 1920, while 664 ha (-96\%) disappeared between 1920 and 1965 (Baud et al. 2015). Detailed diachronic mapping and calculations using GIS tools is thus a powerful mean for representing and quantifying territorial and landscape changes. Additional research in archive documents allows explaining the factors responsible of changes, i.e. intensification of agriculture and systematic drainage of marshes.

Another indicator of the presence of ancient landforms is the inventory and analysis of place names. This approach was used in the area of Saillon (Reynard et al. 2011) (Fig. 10). Place names as Les Moilles, Les Frasses, Grand Blettay, Pro Pourri, Les Maraîches refer to marshes and wet meadows, whereas place names as Les Epineys (indicating thorny vegetation), Les Ilots, Les Iles (gravel deposits of a braided river), Grands Glariers (spreading gravel), Lanches (river bed) reflect former traces of the Rhone River. Les Chantons, which means small hills, record the presence of sand dunes. The detailed study of place names can help understanding geomorphological processes, as was also noted by Sellier (2013).

\section{Geo-education and geotourism}

An application of this research is to improve geo-education and geotourism in the study area. Geo-education is a holistic approach aiming at educating "about our world. A well-rounded geo-education provides young people with a fundamental understanding of how the human and natural worlds work at local, regional, and global scales" (National Geographic 2014). Therefore, geo-education is developed not only at school by combining different disciplines (history, geography, civics, ecology, Earth sciences, etc.) but also through non-formal education experiences. Educational field activities are quite widely 
developed in geoparks (Bitschene and Schüller 2011; Azman et al. 2011), nature parks, and also in urban contexts (Swiercz and Smorzewska 2015), in particular in the framework of geotourism (Hose 1996, 2012; Dowling and Newsome 2006).

In this case characterised by important landform changes induced by human impacts, educational and geotourist activities should not only focus on the comprehension of Earth history (geomorphosites as witnesses of Earth evolution) but also on the complex interactions between society and Earth heritage sites. In particular, the question of destruction of landforms by human activities and infrastructures should be addressed, as well as the needs for geoconservation. A challenge is how to make visible invisible landforms? Cayla et al. (2012) propose the use of 3D reconstruction methods, as was the case for example in Lascaux or Chauvet karstic and prehistoric heritage sites (France). In our case we propose the development of three main geoeducational/geotourist products:

- A bike itinerary could rely the various inventoried geomorphosites and could be used to raise awareness on the geoheritage by tourists and inhabitants. A similar proposal was made by Schneider (2009) in another stretch of the Rhone River plain and it fits well with two important projects in the canton of Valais: the $3^{\text {rd }}$ Rhone River Training, a project of rehabilitation of the Rhone River that also aims at using the streets along the Rhone River as a soft mobility route, and the project "Valais Vélo Tour" launched in 2016 by the organisation Valais-Wallis Promotion with the objective to develop Valais as a bike tourist destination.

- A geo-educational traveling exhibition could focus on the former landscapes of the Rhone River plain. This exhibition would have as main objective to make visible the died landscapes of the Rhone River plain by focusing of course on the $19^{\text {th }}$ and early $20^{\text {th }}$-century landscapes but also on more ancient landscapes such as the Ice Age landscapes, as was realised by Perret (2014) in the Chablais area. The targeted public, in this case, should be the middle class school children and the local population, to make them aware on the landscape evolution and to encourage them to protect geomorphosites as testimonies of former landscapes.

- The third proposed geo-educational/geotourist product is the creation of a mobile application in the framework of the program GeoGuide of the University of Lausanne (http://igd.unil.ch/geoguide; Reynard et al. 2015; Pica et al. submitted). The objective is to disseminate scientific knowledge - related to research projects carried out by University members - to a broad audience by using mobile technologies. The use of interactive tools could allow a dynamic representation of landscape changes, and this project could be combined with the bike itinerary and the exhibition.

\section{Conclusion}

Since the mid- $19^{\text {th }}$ century the anthropic pressure on the Rhone River valley geomorphology has highly increased if compared with the previous centuries. It is due to four main factors: (1) the river training works aimed at reducing flood hazards since the $1860 \mathrm{~s}$; (2) industrialisation of the valley since the late $19^{\text {th }}$ century; (3) development of intensive agricultural crops associated with large-scale drainage since the 1870 s, with an acceleration since the 1920s; (4) urban sprawling since the 1960s, with an acceleration since the 1990s. Thus, embanked channels have replaced braided sectors of the Rhone River, except in the Finges area; wetlands and marshes have been drained, and sand dunes have been completely destroyed for filling the depressions. Therefore, three major landforms of the $19^{\text {th }}$-century river plain have nearly completely disappeared from today landscapes. In this kind of environments, highly modified by human beings, we propose that geomorphosite inventories not only select and assess the visible landforms but also takes into account landforms present in the past decades but now completely hidden or destroyed by human works and infrastructures. For this, several historical testimonies (maps, iconographic material, written archives, place names) can be used and processed through a geohistorical approach. They can thus participate to make visible the ancient landscapes, and be used for geo-educational and geotourist projects. In this sense, they contribute to the awareness of the vulnerability of geomorphosites.

\section{Acknowledgements}

Part of this research was carried out commonly with other researchers. We thank Dominique Baud, Jonathan Bussard, Laetitia Laigre and Benoît Maillard for common work and discussion. We acknowledge Dominique Baud and Jonathan Bussard for GIS processing of Fig. 5. We also acknowledge the collaborators of the State Archives of Valais for their help to the historical researches. We thank the two anonymous referees for useful comments and suggestions, as well as the Guest editors and Kevin Page for the edition of the paper.

\section{References}

Azman A, Halim SA, Liu O, Saidin S, Komoo I (2011) Public education in heritage conservation for geopark community. Procedia - Social and Behavioral Sciences 7(C): 504-511

Baker ARH (2003) Geography and history: Bridging the divide. Cambridge University Press, Cambridge, p. 281

Baud D (2009) Méthodologie pour l'analyse des dynamiques paysagères à partir d'archives cadastrales (XVIIIe et XIXe siècles). L'étude de cas d'un village savoyard: Sardières. Norois 213:21-40 
Baud D, Reynard E (2015) Géohistoire d'une trajectoire paysagère dans la plaine du Rhône valaisan. Analyse du secteur entre Riddes et Martigny (1840-1965). Norois 237:15-31

Baud D, Reynard E, Bussard J (2015) Les transformations paysagères de la plaine du Rhône. Analyse diachronique et cartographie historique (1840-2010). In: Reynard E, Evéquoz-Dayen M, Borel G (eds.). Le Rhône, entre nature et société. Cahiers de Vallesia 29, Sion, pp 225-258

Bini A, Buoncristani JF, Couterrand S, Ellwanger D, Felber M, Florineth D, Graf HR, Keller O, Kelly M, Schlüchter C, Schoeneich P (2009) Switzerland during the Last Glacial Maximum, 1:500,000 map. Swisstopo, Wabern.

Bitschene P, Schüller A (2011) Geo-education and geopark implementation in the Vulkaneifel European Geopark. In: Carena S, Friedrich A., Lammerer B (eds) Geological field trips in Central Western Europe: Fragile Earth International Conference, Munich, September 2011. Geological Society of America Field Guide 22, pp 29-34, doi:10.1130/2011.0022(03).

Braudel F (1949) La Méditerranée et le monde méditerranéen à l'époque de Philippe II. Armand Colin, Paris, p. 1160

Bravard JP (1989) La métamorphose des rivières des Alpes françaises à la fin du Moyen-Age et à l'époque moderne. Bull Soc Géogr Liège 25:145-157

Brilha J (2005) Património geológico e geoconservação: a conservação da natureza na sua vertente geológica. Palimage Editores, Viseu, p. 190

Brilha J (2016) Inventory and quantitative assessment of geosites and geodiversity sites: a review. Geoheritage 8(2):119-134 doi:10.1007/s12371-014-0139-3

Bruschi VM, Cendrero A (2005) Geosite evaluation: can we measure intangible values? Il Quaternario 18(1):293-306

Cayla N, Hoblea F, Biot V, Delamette M, Guyomard A (2012) De l'invisibilité des géomorphosites à la révélation géopatrimoniale. Géocarrefour 87:171-186

Clivaz M (2015) Inventaire des géomorphosites de la plaine du Rhône entre Agarn et Martigny. University of Lausanne, Master's Thesis, p. 111

Coratza P, Giusti C (2005) Methodological proposal for assessment of the scientific quality of geomorphosites. Il Quaternario 18(1):307-313

Crofts R, Gordon JE (2015) Geoconservation in protected areas. In Worboys GL, Lockwood M, Kothari A, Feary S, Pulsford I (eds) Protected area governance and management. ANU Press, Canberra, pp 531-568

De Torrenté C (1964) La correction du Rhône en amont du lac Léman. Département fédéral de l'Intérieur, Berne, p. 135

Dowling RK, Newsome D (2006) (eds) Geotourism: Sustainability, impacts and management. Elsevier, Oxford, p. 290

Egli D, Mancktelow N (2013) The structural history of the Mont Blanc massif with regard to models for its recent exhumation. Swiss J Geosci 106:469-489

Farquet P (1925) Les marais et les dunes de la plaine de Martigny. Bull Murithienne 42:113-159

Franchomme M, Schmidtt G (2012) Les zones humides dans le Nord vues à travers le cadastre napoléonien: les Systèmes d'Information Géographique comme outils d'analyse. Revue du Nord 94:661-680

Gams H (1914) La Grande Gouille de la Sarvaz et les environs. Bull Murithienne 39:125-186

Giusti C (2012) Les sites d'intérêt géomorphologique: un patrimoine invisible? Géocarrefour 87:151-156

Grandgirard V (1997) Géomorphologie, protection de la nature et gestion du paysage. University of Friboug, PhD Thesis, p. 210

Grataloup C (2005) Géographie historique et analyse spatiale: de l'ignorance à la fertilisation croisée. In: Boulanger P, Trochet JR (eds) Où en est la géographie historique? Entre économie et culture. L’Harmattan, Paris, pp 33-42

Grataloup C (2015) Introduction à la géohistoire. Armand Colin, Paris, p. 224

Gray M (2004) Geodiversity. Valuing and conserving abiotic nature. Wiley, Chichester, p. 434

Hose TA (1996) Geotourism, or can tourists become casual rock hounds? In: Bennett MR et al. (eds) Geology at your doorstep: the role of urban geology in Earth Heritage Conservation. The Geological Society, London, pp 207-228

Hose TA (2012) 3G's for modern geotourism. Geoheritage 4:7-24

Hubbard M, Mancktelow N (1992) Lateral displacement during Neogene convergence in the western and central Alps. Geology 20:943-946

Jacob-Rousseau N (2009) Géohistoire/Géo-histoire. Quelles méthodes pour quel récit?. Géocarrefour 84:211-216

Laigre L (2009) Etude diachronique de la dynamique fluviale du Rhône suisse depuis la fin du Petit Age Glaciaire Cartographie paléoenvironnementale sectorielle de la source au Lac Léman. University Paris 1, Master's Thesis, p. 167

Mariétan I (1968) Drame de la lutte contre l'eau dans le Valais. Bull Murithienne 85:51-71

Montané A, Arnaud-Fassetta G, Reynard E (2010) Analyse statistique et modélisation de la variabilité longitudinale du gradient granulométrique du Rhône. Bull Murithienne 127:19-27

Morlot A (1857) Les dunes de sable mouvant de Saxon en Valais. Bull Soc Vaud Sc Nat 5(41):306-307 
National Geographic (2014) Geo-education: Essential preparation for an interconnected world, http://nationalgeographic.org/education/geo-education-essential-preparation-interconnected-world/ (accessed 25.08.2016)

O’Halloran D, Green C, Harley M, Stanley M, Knill J (1994) (eds) Geological and landscape conservation. The Geological Society, London, p. 530

Ozima M (1987) Geohistory. Global evolution of the Earth. Springer, Berlin, p. 165

Panizza M (2001) Geomorphosites: concepts, methods and example of geomorphological survey. Chinese Sci Bull 46 Suppl:4-6

Pasche L (2004) Travaux de correction des cours d'eau en Valais et dans la région de Conthey (1860-1900). Vallesia 59:225246

Pemberton M (2001) Conserving geodiversity, the importance of valuing our geological heritage. National Conference, Geological Society of Australia, p. 7, dpipwe.tas.gov.au/Documents/geocon_abstract.pdf (accessed 05.01.2017)

Pereira P, Pereira D (2010) Methodological guidelines for geomorphosite assessment. Géomorphologie: relief, processus, environnement 2:215-222

Perret A (2014) Géopatrimoines des trois Chablais: identification et valorisation des témoins glaciaires. PhD Thesis, University of Lausanne, http://igd.unil.ch/www/geovisions/45/Geovisions_45_Geopatrimoines_Chablais.pdf (accessed 25.08.2016)

Pica A, Reynard E, Grangier L, Kaiser C, Ghiraldi L, Perotti L, Del Monte M (submitted) GeoGuides, urban geotourism offer powered by mobile application technology

Rey C (2008) Marais du Valais central: appauvrissement de la flore palustre au cours des 150 dernières années. Bull Murithienne 125:11-27

Reynard E (2005) Géomorphosites et paysages. Géomorphologie: relief, processus, environnement 3:181-188

Reynard E (2012) Geoheritage protection and promotion in Switzerland. European Geologist 34:44-47

Reynard E (2009a) Geomorphosites: definitions and characteristics. In: Reynard E, Coratza P, Regolini-Bissig G (eds) Geomorphosites. Pfeil, Munchen, pp 9-20

Reynard E (2009b) Les sources cartographiques pour l'histoire du Rhône valaisan. In: Reynard E, Evéquoz-Dayen M, Dubuis P (eds) Le Rhône: dynamique, histoire et société. Cahiers de Vallesia 21, Sion, pp 63-71

Reynard E, Laigre L, Maillard B (2011) Repérer des géomorphosites disparus: le cas de la plaine du Rhône valaisanne. In: Reynard E, Laigre L, Kramar N (eds) Les géosciences au service de la société. Institut de Géographie, Lausanne, Géovisions 37, pp 55-74

Reynard E (2016) Geoheritage case study: canton Valais, Switzerland. In: Hose TA (ed) Geoheritage and geotourism. A European perspective. Boydell \& Brewer, Woodbridge, pp 279-290

Reynard E, Baud D (2015) Etude géohistorique de l'assèchement de la plaine de Riddes-Martigny (1910-1940). Vallesia 70:255-291

Reynard E, Coratza P (2013). Scientific research on geomorphosites. A review of the activities of the IAG working group on geomorphosites over the last twelve years. Geogr Fis Dinam Quat 36:159-168

Reynard E, Fontana G, Kozlik L, Scapozza C (2007) A method for assessing scientific and additional values of geomorphosites. Geogr Helv 62(3):148-158

Reynard E, Coratza P, Regolini-Bissig G (2009a) (eds) Geomorphosites. Pfeil, Munchen, p 240

Reynard E, Arnaud-Fassetta G, Laigre L, Schoeneich P (2009b) Le Rhône alpin vu sous l'angle de la géomorphologie: état des lieux. In: Reynard E, Evéquoz-Dayen M, Dubuis P (eds) Le Rhône: dynamique, histoire et société. Cahiers de Vallesia 21, Sion, pp 75-102

Reynard E, Kaiser C, Martin S, Regolini G (2015) An application for Geosciences communication by smartphones and tablets. In: Lollino $G$ et al. (eds) Engineering geology for society and territory. Springer, Heidelberg, vol 8, pp 265-268, doi:10.1007/978-3-319-09408-3_46

Reynard E, Perret A, Bussard J, Grangier L, Martin S (2016) Integrated approach for the inventory and management of geomorphological heritage at the regional scale. Geoheritage 8(1):43-60

Schneider V (2009) Valorisation du patrimoine glaciaire de la cluse du Rhône et du Chablais. University of Lausanne, Master's Thesis, p. 217

Sellier D (2013) Patrimoine géomorphologique et toponymie: perception et désignation des montagnes quartzitiques de la façade atlantique nord-européenne (Norvège, Écosse, Irlande). Norois 229:53-75

Serrano E, Gonzáles Trueba JJ (2005) Assessment of geomorphosites in natural protected areas: the Picos de Europa National Park (Spain). Géomorphologie: Relief, processus, environnement 3:197-208

Sharples C (2002) Concepts and principles of geoconservation. Tasmanian Parks \& Wildlife Service website, http://dpipwe.tas.gov.au/Documents/geoconservation.pdf (accessed 05.01.2017) 
Stäuble S (2009) Evolution de la plaine du Rhône suisse du début du XIX ${ }^{\mathrm{e}}$ siècle à nos jours: étude cartographique dans le Valais central. In: Reynard E, Evéquoz-Dayen M, Dubuis P (eds) Le Rhône: dynamique, histoire et société. Cahiers de Vallesia 21, Sion, pp 167-175

Stäuble S, Reynard E (2005) Evolution du paysage dans la plaine du Rhône dans la région de Conthey depuis 1850: les apports de l'analyse des cartes historiques. Vallesia 60:433-456

Stäuble S, Martin S, Reynard E (2008) Historical mapping for landscape reconstruction: examples from the Canton of Valais (Switzerland). In: Mountain Mapping and Visualisation, Proceedings of the $6^{\text {th }}$ ICA Mountain Cartography Workshop, $11-$ 15 February 2008, Lenk, Switzerland, pp 211-217

Strasser A, Heitzmann P, Jordan P, Stapfer A, Stürm B, Vogel A, Weidmann M (1995) Géotopes et la protection des objets géologiques en Suisse - un rapport stratégique. Groupe de travail suisse pour la protection des géotopes, Fribourg, p. 27

Stutenbecker L., Costa A, Schlunegger F (2016) Lithological control on the landscape form of the upper Rhône Basin, Central Swiss Alps. Earth Surf Dynam 4:253-272. doi:10.5194/esurf-4-253-2016

Swiercz A, Smorzewska E (2015) Selected examples of interactive teaching methods in the Centre of Geoeducation in the city of Kielce (Poland). Procedia - Social and Behavioral Sciences 174: 680-686

Tooth S (2009). Invisible geomorphology? Earth Surf Proc Land 34:752-754

Thurre H (2013) Les domaines de la Sarvaz: une agriculture valaisanne en mutation au XXe siècle. Editions Faim de siècle, Fribourg, p. 205

Valla PG, Shuster DL, van der Beek P (2011) Significant increase in relief of the European Alps during mid-Pleistocene glaciations. Nature Geosciences 4:688-692

Weber C, Peter A, Zanini F (2007) Spatio-temporal analysis of fish and their habitat: a case study on a highly degraded Swiss river system prior to extensive rehabilitation. Aquatic Sci 69:162-172

Zanini F, Zanini E, Weber C (2009) Dynamique des paysages et qualité écologique de la plaine du Rhône en amont du Léman, de 1850 à 2003. In: Reynard E, Evéquoz-Dayen M, Dubuis P (eds) Le Rhône: dynamique, histoire et société. Cahiers de Vallesia 21, Sion, pp 103-113

\section{Figure captions}

Fig. 1. Localisation of the study area A. The study area in the Rhone River watershed (rectangle: location of Fig. 1B); B. The investigated area (with location of Fig. 6 and 10); C. The Rhone River in the Finges area; here the river has been poorly trained and the braided pattern is well visible; D. The Rhone River in Sion; here the river is completely embanked ant the former fluvial landforms (braided channels) have disappeared (Photographs: E. Reynard).

Fig. 2. Two methodological approaches: A. Details of the geomorphosite assessment method (from Reynard et al. 2016, modified); B. Data and aims of the geohistorical analysis.

Fig. 3. Selection procedure of landforms to be assessed, based on spatial and temporal criteria (from Clivaz 2015, modified).

Fig. 4. The 28 inventoried geomorphosites presented according to the geomorphological processes (from Clivaz 2015, modified).

Fig. 5. Landforms disappeared in the fluvial plain between Sion and Martigny since the mid-19 ${ }^{\text {th }}$ century: A. Dunes and waterrelated landforms in the late $19^{\text {th }}$ century (modified from Baud et al. 2015); B. Evolution of water-related landforms in the first half of $20^{\text {th }}$ century (modified from Baud et al. 2015).

Fig. 6. Examples of invisible geomorphosites and testimonies used for their revelation. A. Photograph of the Sarvaz dunes (site 23) with extraction operations in 1927 (Source: Médiathèque Valais); B. Braided channels of the Rhone River at the beginning of the $19^{\text {th }}$ century in the area of Saillon (Source: State Archives of Valais, AEV DTP/Plans/Rhône, 1); C. Two maps showing the evolution of the braided sector of Chalais (site 8): Dufour Map (1844) and Siegfried Atlas (1907), respectively before and after river training works; D. Sketch of Praz-Pourris moor around 1850 and evolution through time (modified from Stäuble and Reynard 2005).

Fig. 7. Intrinsic value (scientific and additional values) of the geomorphosites (from Clivaz 2015, modified).

Fig. 8. Integrity, damages, threats and protection status of the geomorphosites (from Clivaz 2015, modified).

Fig. 9. Visit conditions and educational potential of the geomorphosites (from Clivaz 2015, modified).

Fig. 10 Place names in the area of Saillon reproduced on a high-resolution DTM (from Reynard et al. 2011, modified; DTM swisstopo). 
Fig. 1

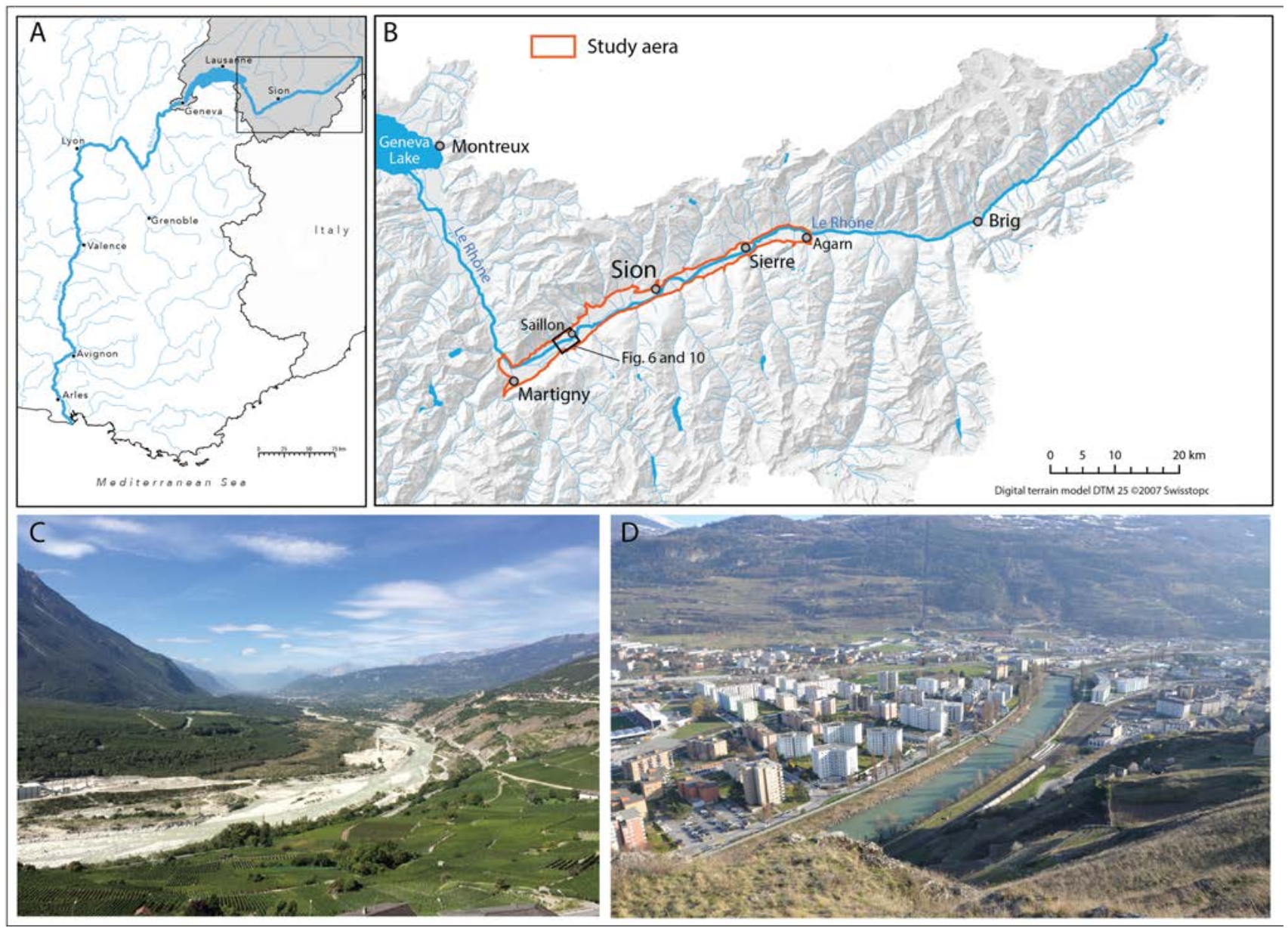


Fig. 2

\begin{tabular}{|c|c|c|c|}
\hline A & \multicolumn{3}{|c|}{ Geomorphosite assessment method } \\
\hline \multicolumn{4}{|c|}{ Documentation of the site } \\
\hline \multicolumn{3}{|c|}{$\begin{array}{l}\text { General data } \\
\text { Identification code, name, location, coordinates, } \\
\text { min and max altitude, type, size, property, map, } \\
\text { pictures, schemes }\end{array}$} & $\begin{array}{l}\text { Descriptive data } \\
\text { - description } \\
\text { - morphogenesis }\end{array}$ \\
\hline \multicolumn{2}{|c|}{$\begin{array}{l}\text { Assessment of the } \\
\text { intrinsic value }\end{array}$} & \multicolumn{2}{|c|}{$\begin{array}{l}\text { Use and management } \\
\text { characteristics }\end{array}$} \\
\hline \multirow{2}{*}{ 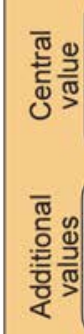 } & $\begin{array}{l}\text { Scientific value } \\
\text { - integrity } \\
\text { - representativeness } \\
\text { - rareness }\end{array}$ & \multirow{2}{*}{ 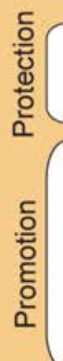 } & $\begin{array}{l}\text { Protection status } \\
\text { Damages and threats }\end{array}$ \\
\hline & $\begin{array}{l}\text { Ecological value } \\
\text { Aesthetic value } \\
\text { Cultural value }\end{array}$ & & $\begin{array}{l}\text { Visit conditions } \\
\text { - accessibility } \\
\text { - security } \\
\text { - site context } \\
\text { - tourism infrastructures } \\
\text { Education } \\
\text { - interpretive facilities } \\
\text { - educational interest }\end{array}$ \\
\hline \multicolumn{4}{|c|}{ Synthesis } \\
\hline \multicolumn{2}{|c|}{$\begin{array}{l}\text { Intrinsic value } \\
\text { Use and management } \\
\text { Management measures }\end{array}$} & \multicolumn{2}{|r|}{$\begin{array}{l}\text { References } \\
\text { Assessor's data } \\
\text { Annexes }\end{array}$} \\
\hline
\end{tabular}

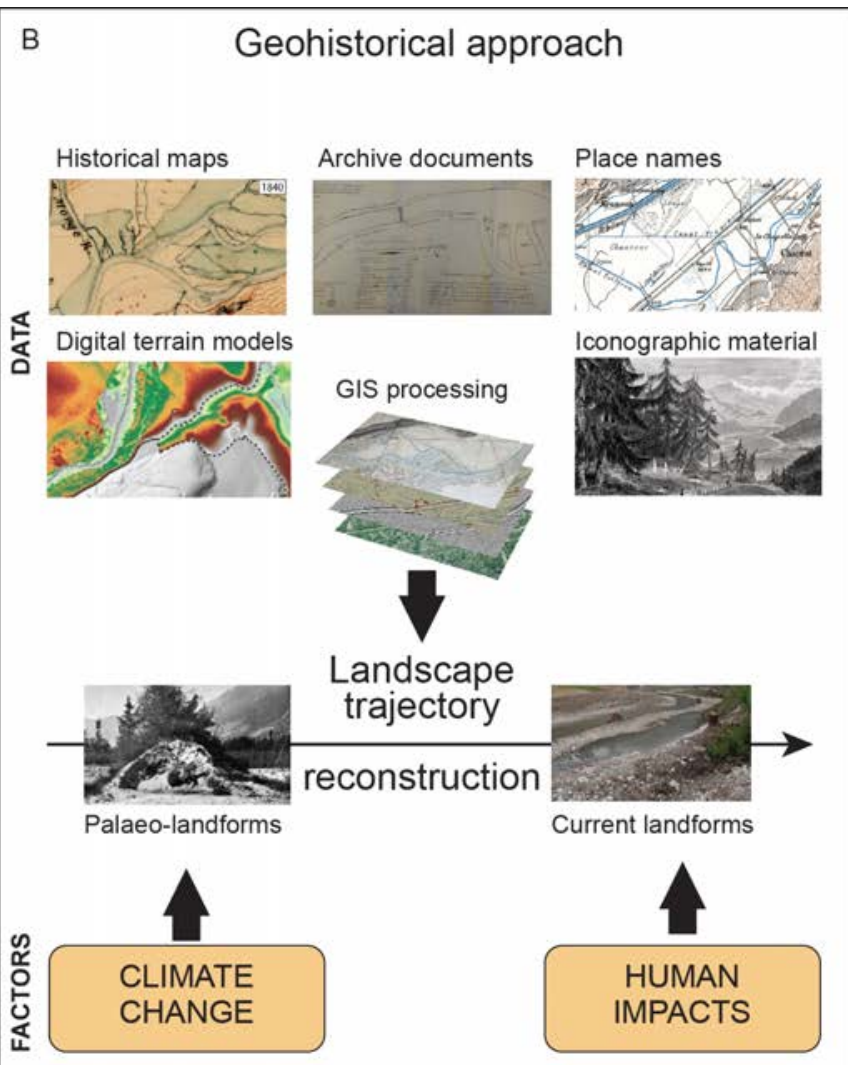


Fig. 3

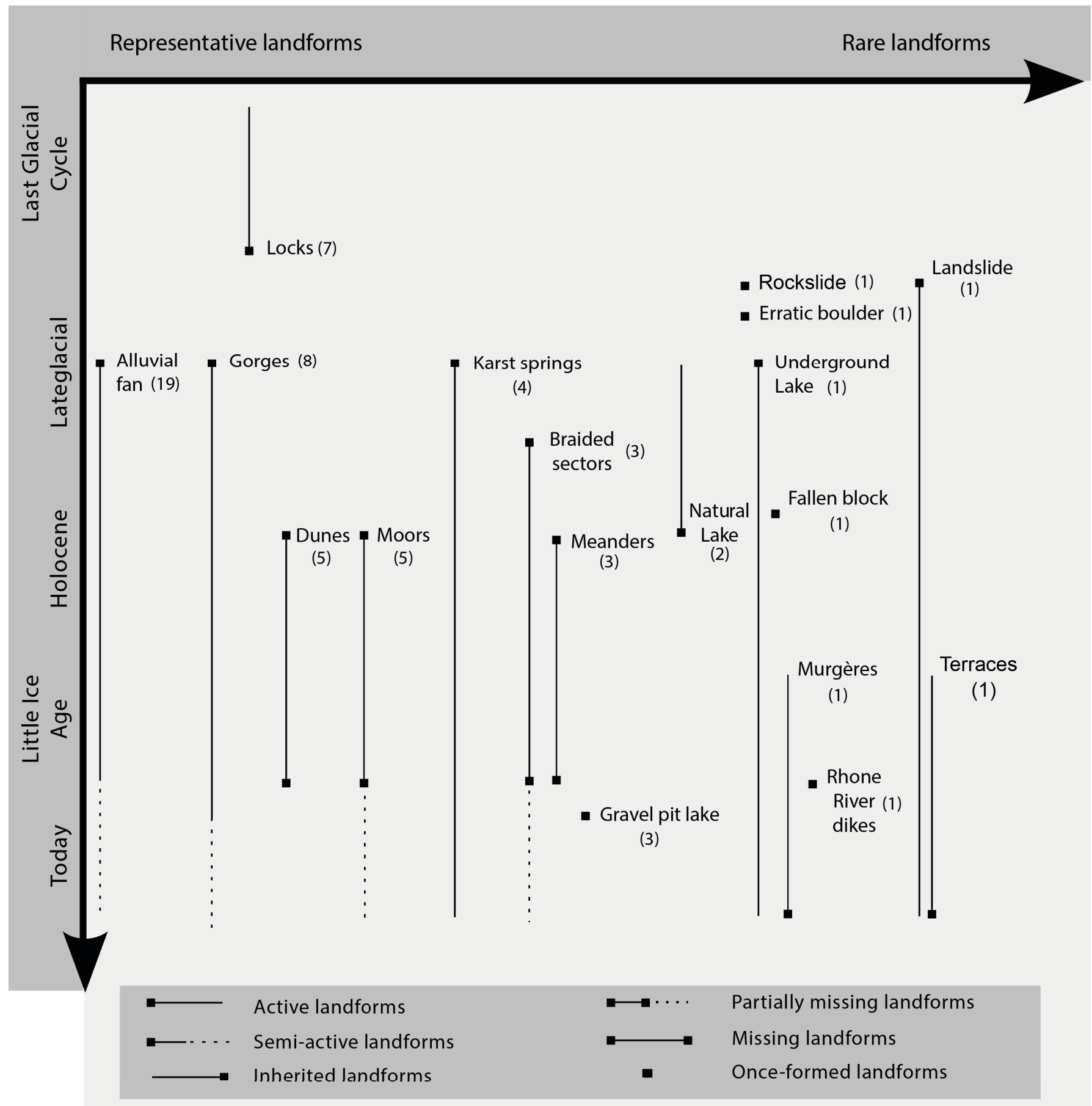


Fig. 4

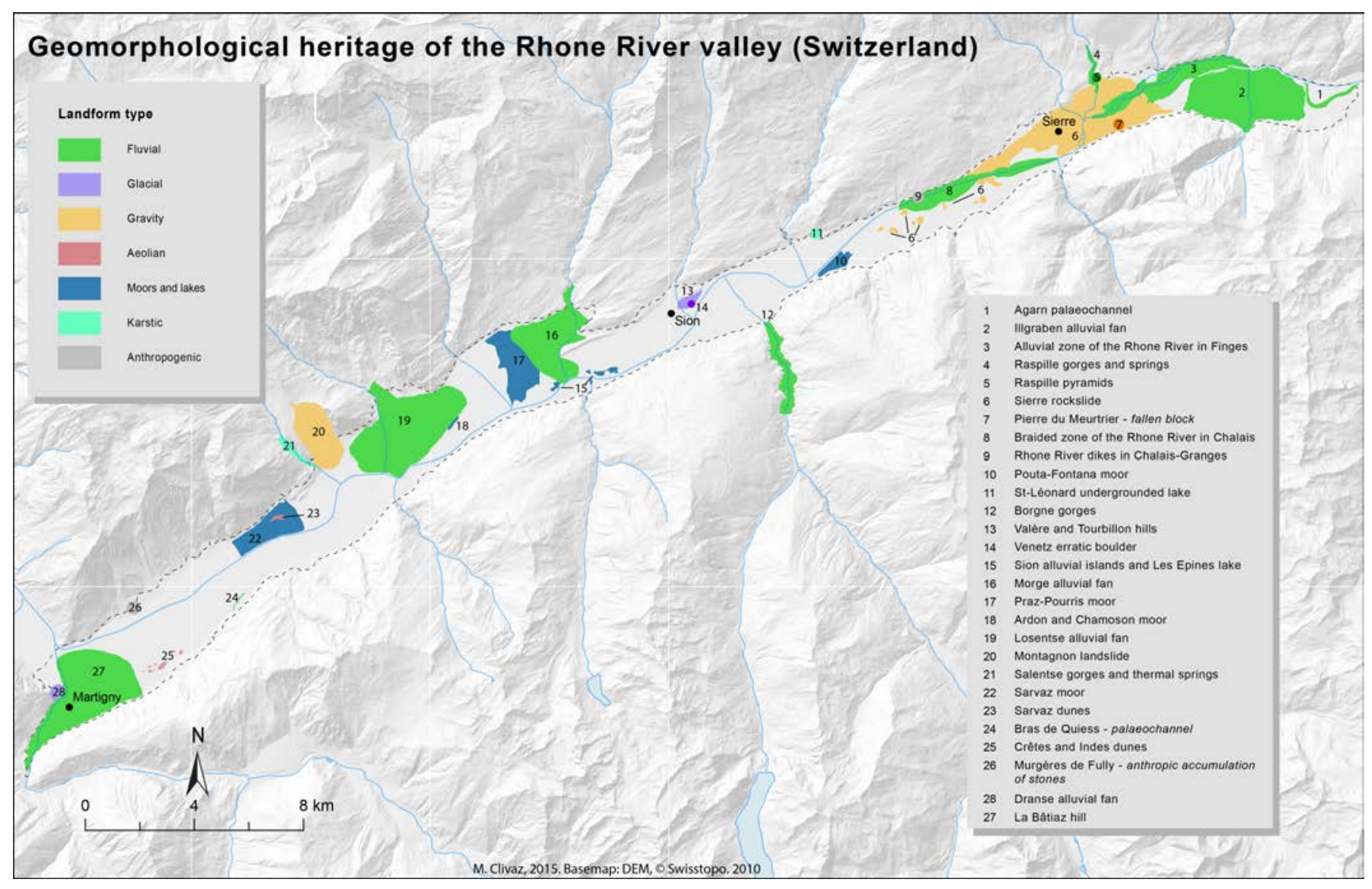


Fig. 5 

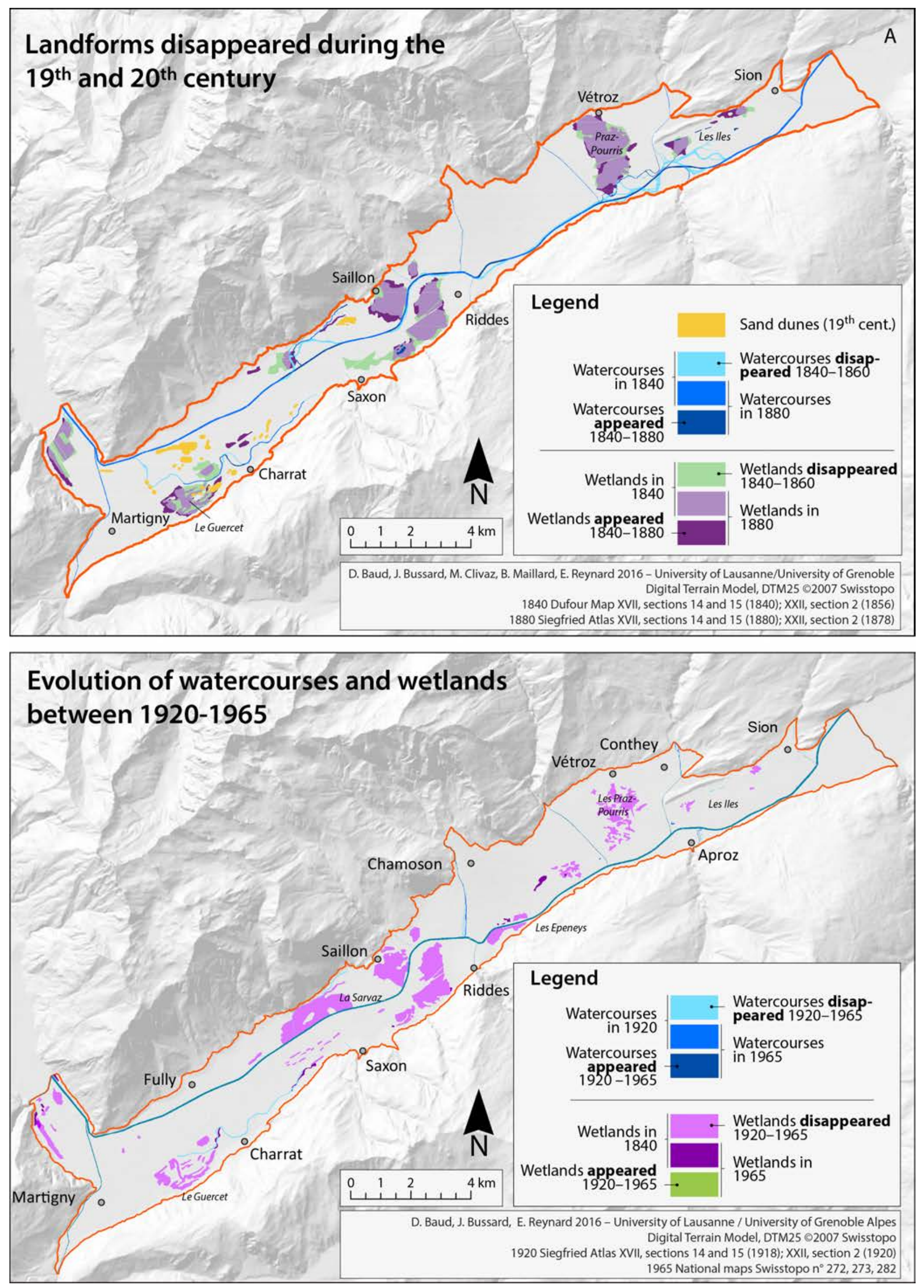
Fig. 6
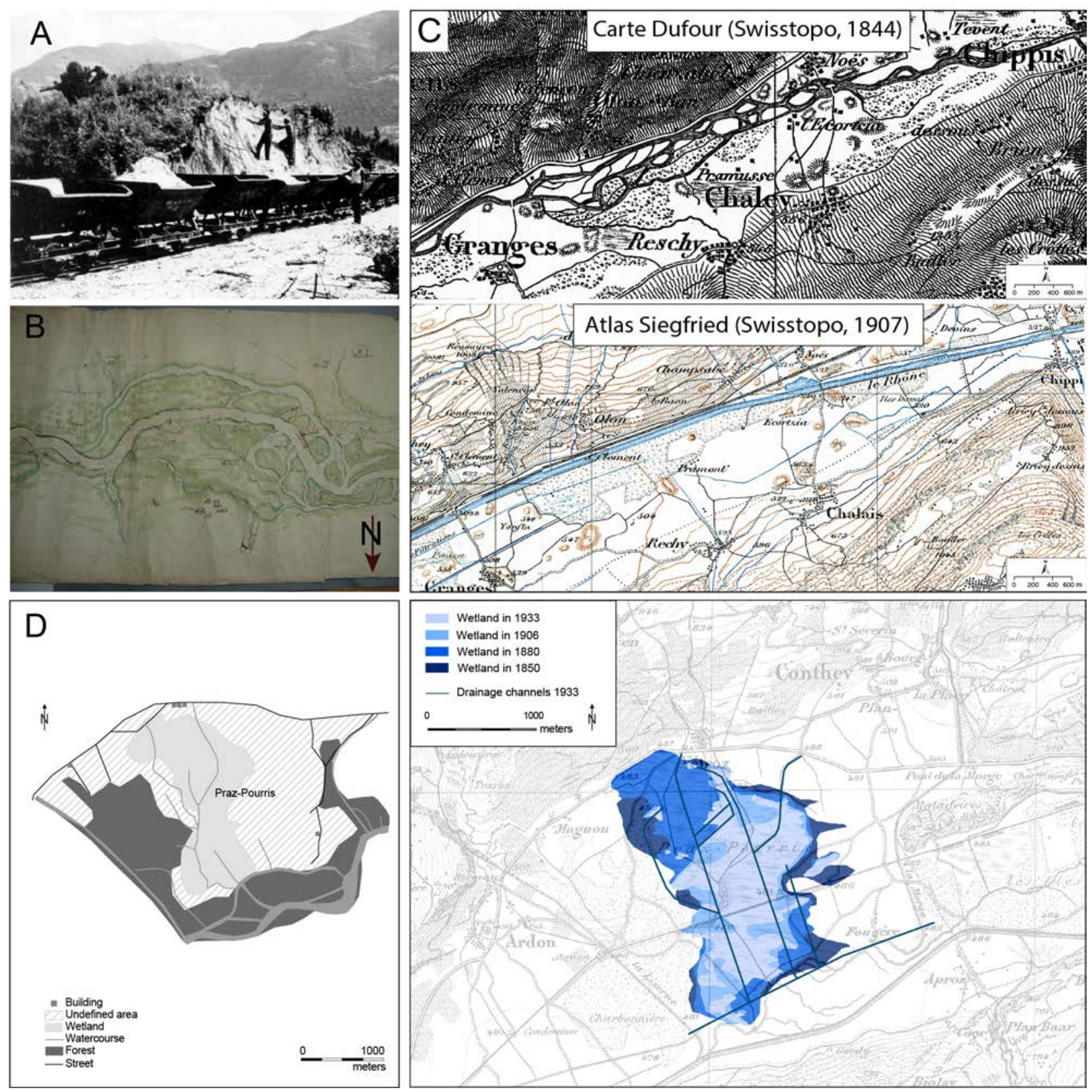
Fig. 6
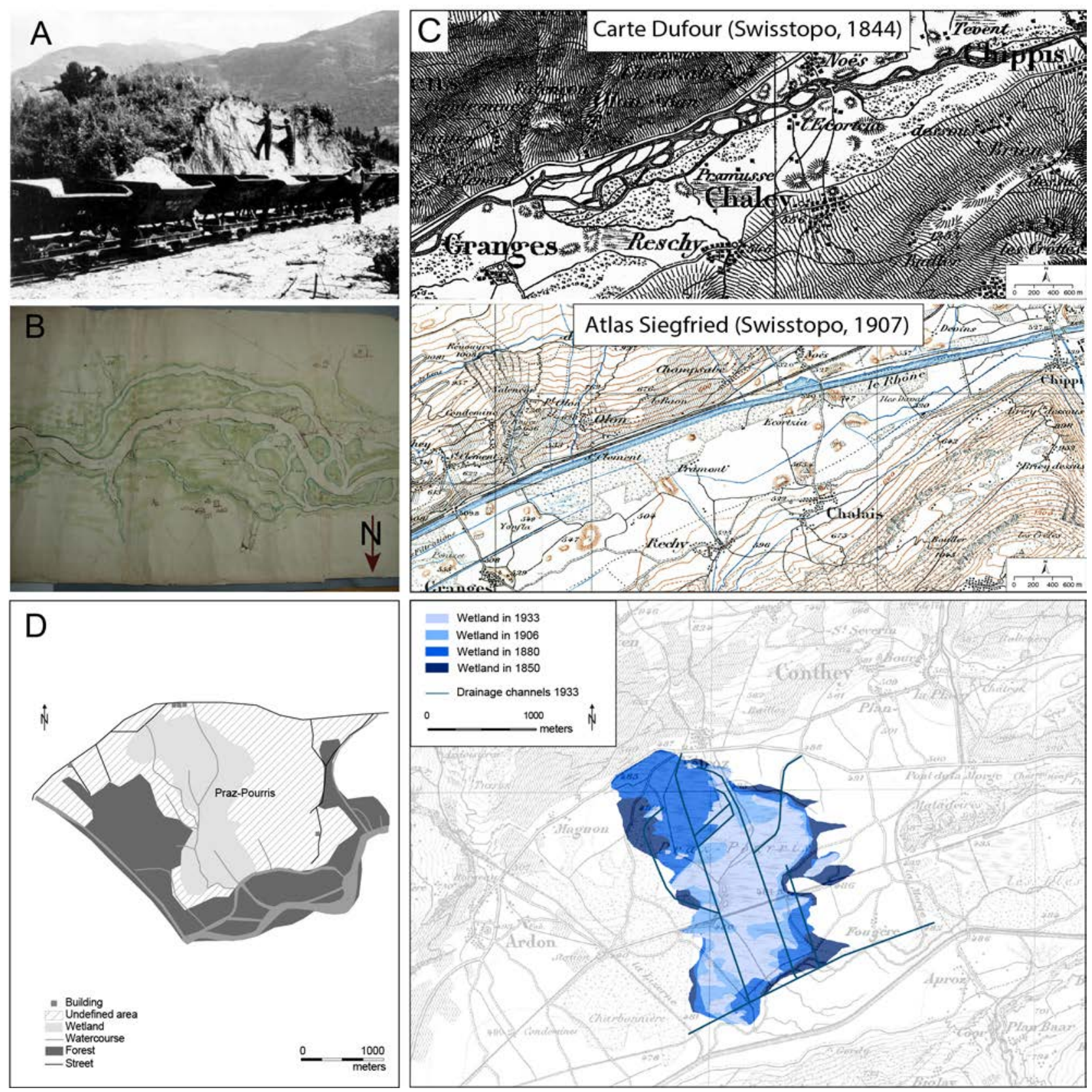
Fig. 7

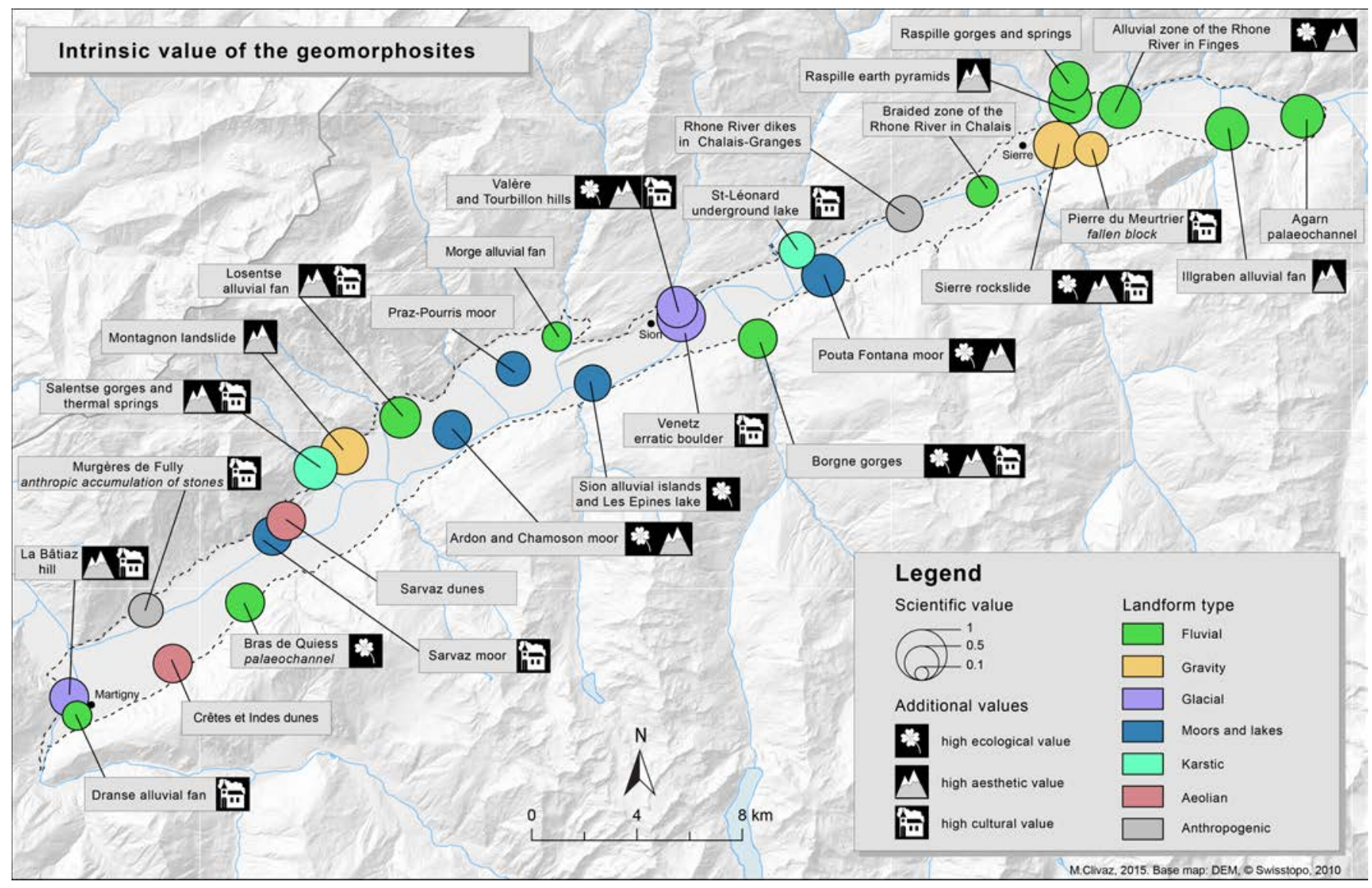


Fig. 8

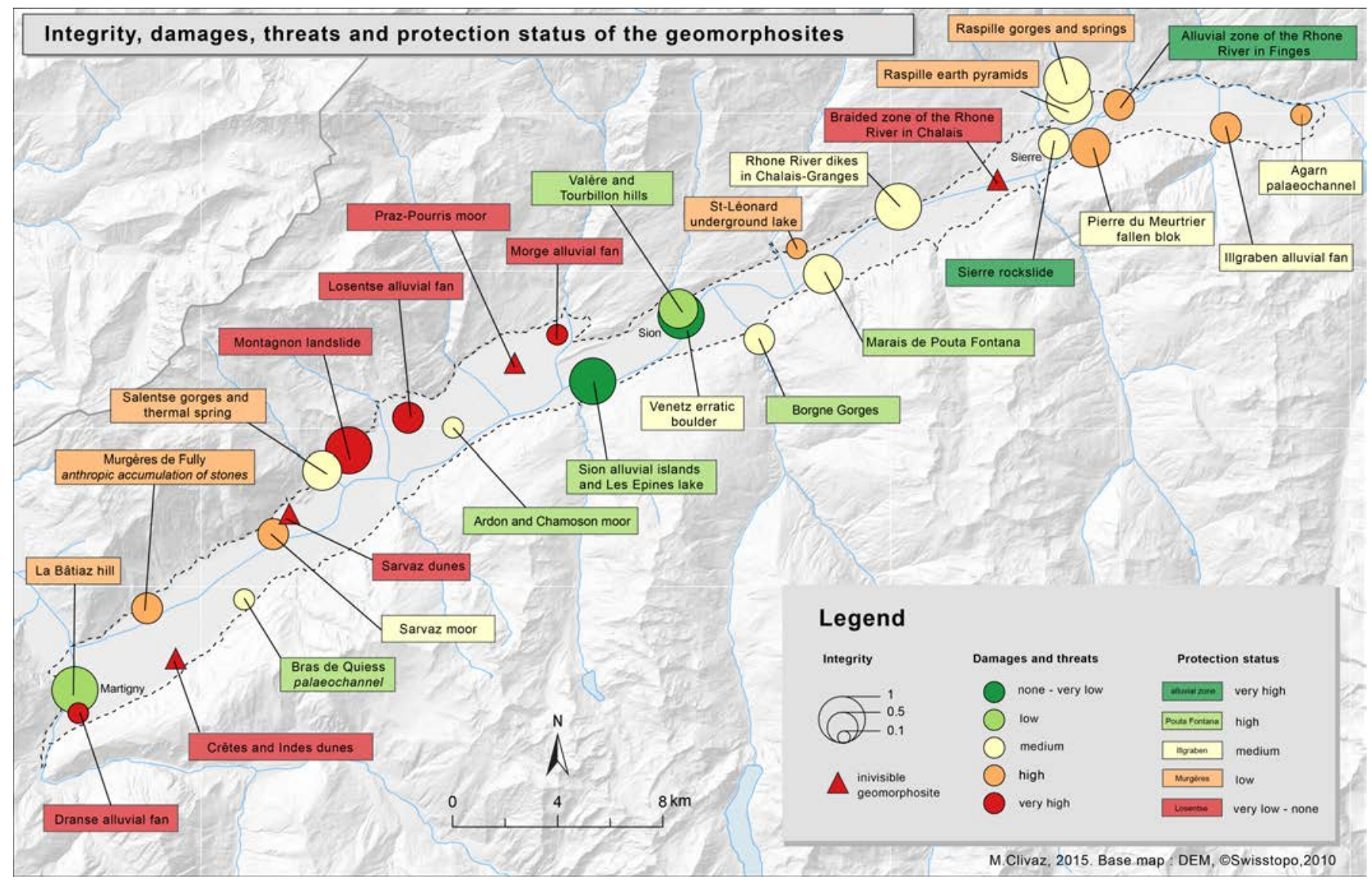


Fig. 9

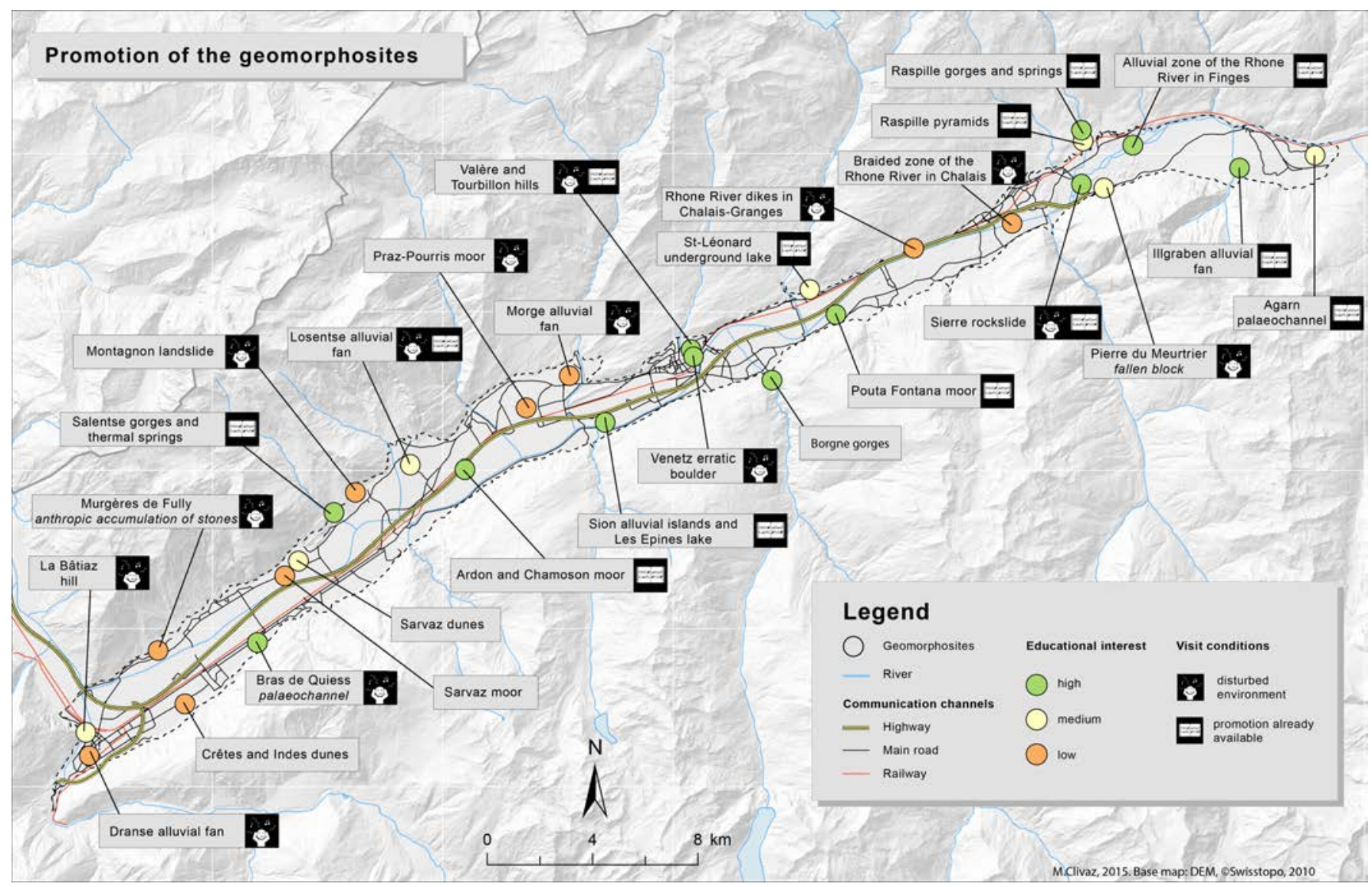


Fig. 10

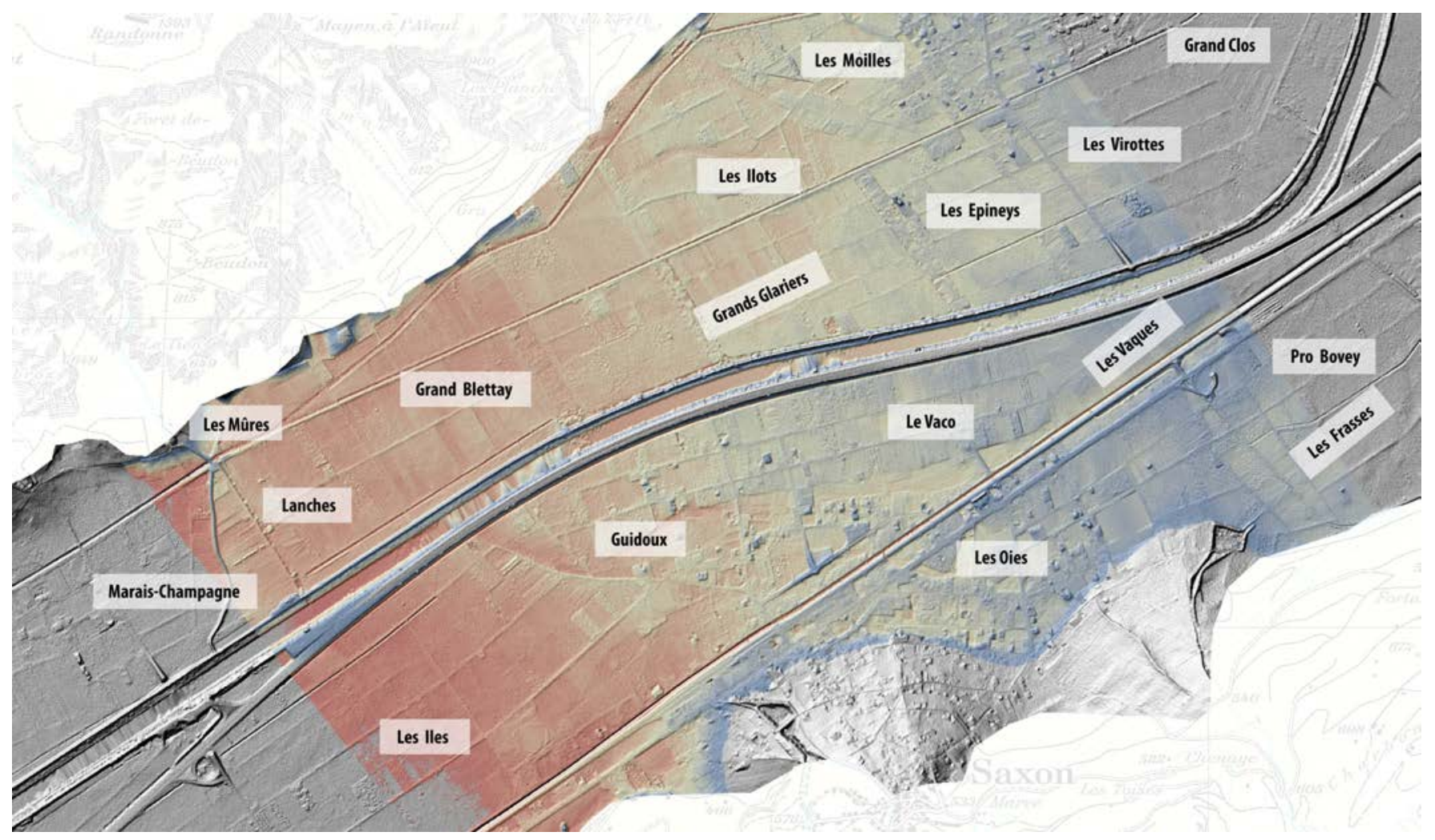

